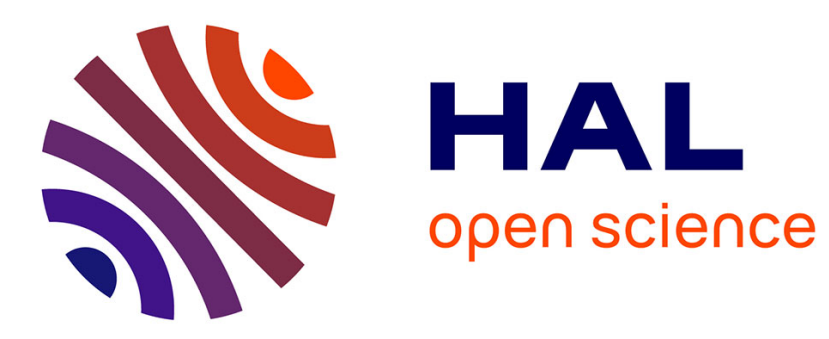

\title{
Resurgence of measles in the French military forces in 2010
}

\author{
A. Mayet, C. Verret, R. Haus-Cheymol, S. Duron, F. Laval, K. Sbai-Idrissi, P. \\ Imbert, M. Janville, P. Munoz, M. Armand-Tolvy, et al.
}

\section{- To cite this version:}

A. Mayet, C. Verret, R. Haus-Cheymol, S. Duron, F. Laval, et al.. Resurgence of measles in the French military forces in 2010. European Journal of Clinical Microbiology and Infectious Diseases, 2011, 30 (8), pp.1023-1026. 10.1007/s10096-011-1189-y · hal-00669196

\section{HAL Id: hal-00669196 https://hal.science/hal-00669196}

Submitted on 12 Feb 2012

HAL is a multi-disciplinary open access archive for the deposit and dissemination of scientific research documents, whether they are published or not. The documents may come from teaching and research institutions in France or abroad, or from public or private research centers.
L'archive ouverte pluridisciplinaire HAL, est destinée au dépôt et à la diffusion de documents scientifiques de niveau recherche, publiés ou non, émanant des établissements d'enseignement et de recherche français ou étrangers, des laboratoires publics ou privés. 
Resurgence of measles in the French military forces in 2010

Authors

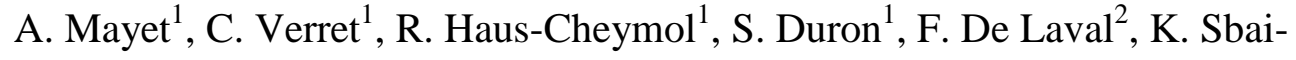

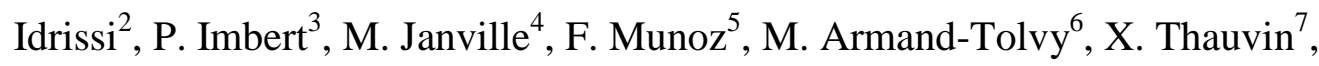 C. Decam ${ }^{2}$, J-B. Meynard ${ }^{1}$, X. Deparis ${ }^{2}$, R. Migliani ${ }^{1}$.

Institutions

1. Département d'épidémiologie et de santé publique Nord, École du Val-deGrâce, Paris

2. Département d'épidémiologie et de santé publique Sud, Institut de médecine tropicale du Service de santé des armées, Marseille.

3. Service de pathologie infectieuse et tropicale, Hôpital d'instruction des armées Bégin, Saint Mandé.

4. Service médical, $4{ }^{\text {ème }}$ groupement d'escadron de hussard, Metz.

5. Service médical, Base de défense, Monthléry.

6. Service médical, $526^{\text {ème }}$ bataillon du train, Saint Germain en Laye.

7. Institut géographique national, Saint Mandé.

\section{Corresponding author: Aurélie Mayet}

Département d'Épidémiologie et de Santé Publique Nord, École du Val-deGrâce. Ilot Bégin, 69 avenue de Paris 94160 Saint Mandé. France

Tel. 33143984996

Fax. 33143985433

Email:aurelie_marie@hotmail.fr

\section{Running title: Measles in the French armed forces}




\title{
Resurgence of measles in the French military forces in 2010
}

\begin{abstract}
Aims

Since the start of 2010 there has been a flare-up of measles in France, following on the resurgence observed in 2008. The aim of this study was to present results of the epidemiological surveillance of measles in the French armed forces and to describe the increase in incidence.
\end{abstract}

\section{Population and methods}

Measles was surveyed from 1992 to 2010 . Criteria for report were those used for French national compulsory notification. The data, concerning active military personnel, were provided by the physicians in the armed forces using anonymous data collection forms.

\section{Results}

Between 1992 and July 2010, 689 cases of measles were notified. Since 2002, the mean incidence rate was 1 case per 100,000. A significant increase has been observed for 2010 (13.9 cases per 100,000 in 2010 versus 1.8 in 2009). The 28 cases reported in 2010 involved 5 clusters and 3 isolated cases. The mean age of affected subjects was 27 years. Only $30 \%$ of cases had been vaccinated.

\section{Conclusions}

The epidemic resurgence of measles observed in 2010 in the French armed forces follows the same pattern as that observed nationally and at European level, and can be seen as the likely consequence of inadequate vaccination cover.

\section{Keywords}

Adult, armed forces, France, measles, vaccination. 


\section{Introduction}

Measles is a highly infectious disease caused by a virus of the Paramyxoviridae family, and is still one of the main causes of death among young children under 5 years old in the world [1]. The measles vaccine was introduced into the vaccination calendar in France in 1983 for infants, which led to a reduction of more than $90 \%$ from the number of cases of measles at the end of the $1980 \mathrm{~s}$ [2]. To achieve the eradication of measles in France in 2010, an objective shared with the other European countries, a national plan was launched in 2005 [3]. From this date a two-doses vaccination scheme with the measles/mumps/rubella (MMR) vaccine was recommended in early childhood, and measles was returned to the status of a notifiable disease. Recommendations for later vaccination today target not only children and adolescents, but also young adults that have not been vaccinated, and health professionals. While in 2006 and 2007, 40 and 44 cases respectively were reported in France [4], a resurgence of measles was detected at the start of 2008 [5]. In the French military forces, measles has been under surveillance since 1992 on account of its highly contagious nature, and the risk of it affecting operational capacities. While the disease has been rare since 2002, with an average of 2 reported cases a year, a small resurgence was noted in 2008 and 2009, with 5 cases on average per year, prior to the flare-up observed since the start of 2010 with 28 cases observed over a period of 7 months.

The aim of the present work was to present the results of the epidemiological surveillance of measles in the French armed forces, and to describe the increase in incidence observed.

\section{Subjects and methods}

The epidemiological surveillance implemented in the armed forces concerns all the active military personnel whatever the place in which medical provision was instated, whether civilian or military. The criteria for notification of measles comprise several case definition parameters, in accordance with French national compulsory notification criteria [6]: 
- biologically confirmed case: isolation of the measles virus or positive PCR (Polymerase Chain Reaction) analysis in a throat, nasopharyngeal, urinal or blood swab, or significant rise in measles seric antibodies (at least fourfold increase of IgG level in absence of recent vaccination), or presence of anti-measles $\operatorname{IgM}$, either in serum or in saliva;

- clinically confirmed case: fever over $38.5^{\circ} \mathrm{C}$ in association with generalised maculopapular rash, and at least one of the following signs: oculo-nasal catarrh, cough, Koplik's spots, in an epidemic setting or after contact within 7 to 18 days with a confirmed case.

In addition to this, cases are considered as clusters when 3 or more cases of measles are grouped, among which at least one case was confirmed biologically, in a given geographical zone over a limited time period.

Data were issued from epidemiological surveillance from 1992 to 2010 . For cases reported since 2006, military physicians completed a notification form providing information concerning the patient, the clinical symptoms, the results of measles laboratory confirmation and the vaccination status. Data were analyzed with the Epi-Info 6.04d.fr software (CDC Atlanta).

\section{Results}

Since 1992, 689 cases of measles have been notified to the French armed forces (figure 1). While the mean incidence rate between 1992 and 1997 was 18.1 cases p.100,000 persons-years (P.Y.), a marked decrease in incidence was observed from 1998. From 2002, incidence rates were very low, around 1 case p.100,000 P.Y.. Between January $1^{\text {st }}$ and July $31^{\text {st }} 2010$, a very marked increase in the incidence rate for measles has been observed in the armed forces: 13.9 cases p.100,000 P.Y. (28 cases) versus 1.8 p.100,000 P.Y. in 2009 (6 cases) and 1.2 p.100,000 P.Y. in 2008 (4 cases) $\mathrm{p}<0.001$. 
The 24 cases notified in metropolitan France in the first half of 2010 were spread over 5 clusters, ranged from 2 to 9 cases, for a total of 21 cases, 3 cases being apparently isolated (figure 2). Another cluster of 4 cases was notified among soldiers in Chad. The mean age of affected subjects was 27 years (range 20-43). Only two cases were women (7.1\%). Fever over $38.5^{\circ} \mathrm{C}$ was observed in $96.4 \%$ of cases (27/28). All cases presented rash, generalised in $85.7 \%$ of cases $(24 / 28)$. Cough (26/28 or $92.9 \%)$ and oculo-nasal catarrh $(23 / 28$ or $82.1 \%)$ were also frequently noted. Four cases (14.3\%) were complicated by pneumonia, with favourable evolution. Fifteen cases were hospitalised (53.6\%), the others stayed at home on sick leave. Measles was confirmed by a laboratory test in $67.9 \%$ of cases (19/28), most often via the presence of IgM in the serum. PCR was performed in five cases, and proved positive. Information on the vaccination status was available for 20 cases (71.4\%), among which only six had been vaccinated (6/20 or 30.0\%): 5 with one dose and 1 with two doses. Questioning of the index cases in the clusters found no extra-professional source of infection. Vaccination status for index cases was available for 4 clusters: the subjects concerned had never been vaccinated.

The investigation and management of these clusters was carried out by the military epidemiology and public health departments (DESPs), which supervised the detection of secondary cases and the identification of contact subjects for the index case so as to instate initial vaccination measures or post-exposure vaccination [5]. The DESPs were also responsible for notification to the local health departments, who dealt with civilian contacts.

\section{Discussion}

After a notable decrease in incidence after 2002, measles became virtually absent from the French armed forces. The start of 2010 saw a flare of grouped cases, in particular in the Paris area and the north-eastern quarter of France. 
These results appear to follow patterns observed in the general population. Indeed, the incidence rate for measles in the general population, below 0.1 cases p.100,000 P.Y. in 2006 and 2007 (around 0.3 among the military) suggested the possibility of the eradication of measles in France [7]. However a resurgence was noted from 2008, with a national incidence rate of 1.0 cases p.100,000 P.Y. (1.2 among the military) [2], followed by a flare at the start of 2010 according to provisional indications provided by the Institut de Veille Sanitaire (health watchdog organisation): 1,972 cases were notified in France between January $1^{\text {st }}$ and May $31^{\text {st }}$ (compared to 1,544 for the whole of 2009), which amounts to an incidence rate of 3.2 cases p.100,000 P.Y. [8]. This increase, also observed in other European countries [9-10], was not unexpected, given the fact that the vaccination cover is not sufficient to halt the transmission of the virus [11]. An analysis of 88 clusters investigated in 2008 and 2009 in French population showed a median vaccination cover of $56 \%$ for the first MMR vaccination dose and 51\% for the second [12]. Vaccination cover appeared similar in French military forces (45.9\% in 2002) [13]. The present epidemiological situation is thus the result of the progressive accumulation of non-vaccinated individuals, many of whom have grown up without ever encountering the virus, as can be seen from the age distribution of cases. The mean age for contracting the disease has risen: the proportion of cases of measles occurring in individuals older than 20 rose from $17 \%$ to $38 \%$ between 2008 and 2010, which gives incidence rates of 0.2 and 1.2 cases p.100,000 P.Y. respectively [7-8]. It should also be noted that complications and fatalities increase with the age at which the disease occurs.

It can however be noted that the later age of disease occurrence is not sufficient on its own to explain the incidence rates among the military, mainly individuals over 20 years of age. The rates are nearly 6 times higher than in the general population for this age group in 2008 and 2010. This could be explained by an under-estimation of incidence in civilian environments. Indeed, only $51 \%$ of the cases investigated by the French civilian health departments between 2008 and 2009 had been the subject of official notification [12]. Another explanation could be provided by the military lifestyle, since they most often live in closed communities, and have activities that foster close 
contacts and hence the transmission of the disease. Several individuals in the series studied here were indeed infected during training sessions, which involve sports activities and lessons in enclosed lecture rooms [14]. The more confined lifestyle at the time of military service, which was aborted in 1996, could also explain high incidence rates observed in the 90'.

As a conclusion, the epidemic resurgence of measles observed this year in the French armed forces follows the pattern observed in the general population both in France and in Europe. The military do however appear to be a relatively exposed population on account of their community lifestyle, particularly in operation theatres. The armed forces, who since 2008 have practised re-vaccination against pertussis, another disease that has shifted towards adulthood [15], integrated MMR vaccination into the calendar in 2009.

Acknowledgements: the authors would like to thank all the physicians in the different military units, who by the quality of their notification procedures played an active part in the epidemiological surveillance network in the armed forces.

\section{REFERENCES.}

1. World Health Organization. Available at :http://www.who.int/mediacentre/factsheets/fs286 /fr/index.html, accessed on August 3, 2010.

2. Parent du Châtelet I, Antona D, Waku-Kouomou D, Freymuth F, Maine C, Lévy-Bruhl D. La rougeole en France en 2008 : bilan de la déclaration obligatoire (Measles in France: 2008 data of mandatory notification). Bull Epid Hebdo 2009;39-40:415-19.

3. Plan national d'élimination de la rougeole et de la rubéole congénitale (French national plan for eradication of measles and rubella. Available at: http://www.sante.gouv.fr/htm/dossiers/rougeole/plan_national.htm, accessed on August 3, 2010. 
4. Parent du Châtelet I, Waku-Kouomou D, Freymuth F, Maine C, Lévy-Bruhl D. La rougeole en France : bilan de 24 mois de surveillance par la déclaration obligatoire - juillet 2005-juin 2007 (Measles in France: 24 months report of mandatory notification, July 2005-June 2007). Bull Epid Hebdo 2007; (51-52):445-9.

5. Parent du Châtelet I, Floret D, Antona D, Lévy-Bruhl D. Measles resurgence in France in 2008, a preliminary report. Eurosurveillance 2009;14(6):1-3.

6. Direction générale de la santé. Circulaire nDGS/RI1/2009/334 relative à la transmission obligatoire de données individuelles à l'autorité sanitaire en cas de rougeole et la mise en œuvre de mesures préventives autour d'un cas ou de cas groupés (Circular letter concerning the mandatory notification of measles cases and the implementation of prophylactic measures around a case or a cluster of cases). Available at: http://www.santesports.gouv.fr/IMG/pdf/09_334t0pdf, accessed on January 17, 2011.

7. Guérin N. Vaccination contre la rougeole : où en sommes-nous en France en 2006 ? (Measles immunisation: where are we in France in 2006?). J Pediatr Pueric 2007;20:1-8.

8. Institut de veille sanitaire. Données de déclaration obligatoires de la rougeole - Bilan provisoire au 31 mai 2010 (Mandatory notification of measles: provisional results at May, 31 2010). Available at: http://www.invs.sante.fr/recherche/index2.asp?txtQuery =rougeole, accessed on August 3, 2010.

9. Pervanidou D, Horefti E, Patrinos S, Lytras T, Triantafillou E, Mentis A, Bonovas S, Panagiotopoulos T. Spotlight on measles 2010: Ongoing measles outbreak in Greece, January-July 2010. Euro Surveill. 2010;15(30):pii=19629. Available at: http://www.eurosurveillance.org /ViewArticle.aspx?ArticleId=19629, accessed on August 3, 2010.

10. Groth C, Böttiger BE, Plesner A, Christiansen AH, Glismann S, Hogh B. Nosocomial meas les cluster in Denmark following an imported case, December 2008-January 2009. Eurosurveillance 2009;14(8):1-3. 
11. Muscat M, Bang H, Wohlfahrt J, Glismann S, Molbak K. Measles in Europe: an epidemiological assessment. Lancet 2009;373:383-9.

12. Stoll J, Dennetière G, Collioud-Marichallot L, Langely L, Escourolle D, Parent du Châtelet I. Foyers de rougeole survenus entre janvier 2008 et avril 2009 en France : résultats d'une enquête auprès des Ddass et des Cire (Measles outbreaks in France from January 2008 to April 2009: results of a survey carried out by the local health authorities (DDASS) and the Interregional Epidemiological Units (CIRE)). Bull Epid Hebdo 2009;39-40:419-23.

13. De Laval F, Simon F, Haus R, Spiegel A. Lesser long-term immunogenicity of mumps valence after MMR vaccine. Pediatr Infect Dis J 2010; in press.

14. Matzkin H, Regev S, Nili E. A measles outbreak in the Israel Defense Forces during the 1982 epidemic. Isr J Med Sci 1985;21:351-5.

15. Mayet A, Berger F, Haus-Cheymol R, Pommier de Santi V, Verret C, Ollivier L, Duron S, Spiegel A, Deparis X, Migliani R. Surveillance épidémiologique de la coqueluche dans les armées françaises en 2007 (Pertussis surveillance in French military forces in 2007). Med Mal Infect 2010;40:81-7. 
Figure 1: incidence and incidence rates (p.100,000 persons-years) of notified cases of measles in the French armed forces between January $1^{\text {st }} 1992$ and July $31^{\text {st }} 2010(\mathrm{n}=689)$

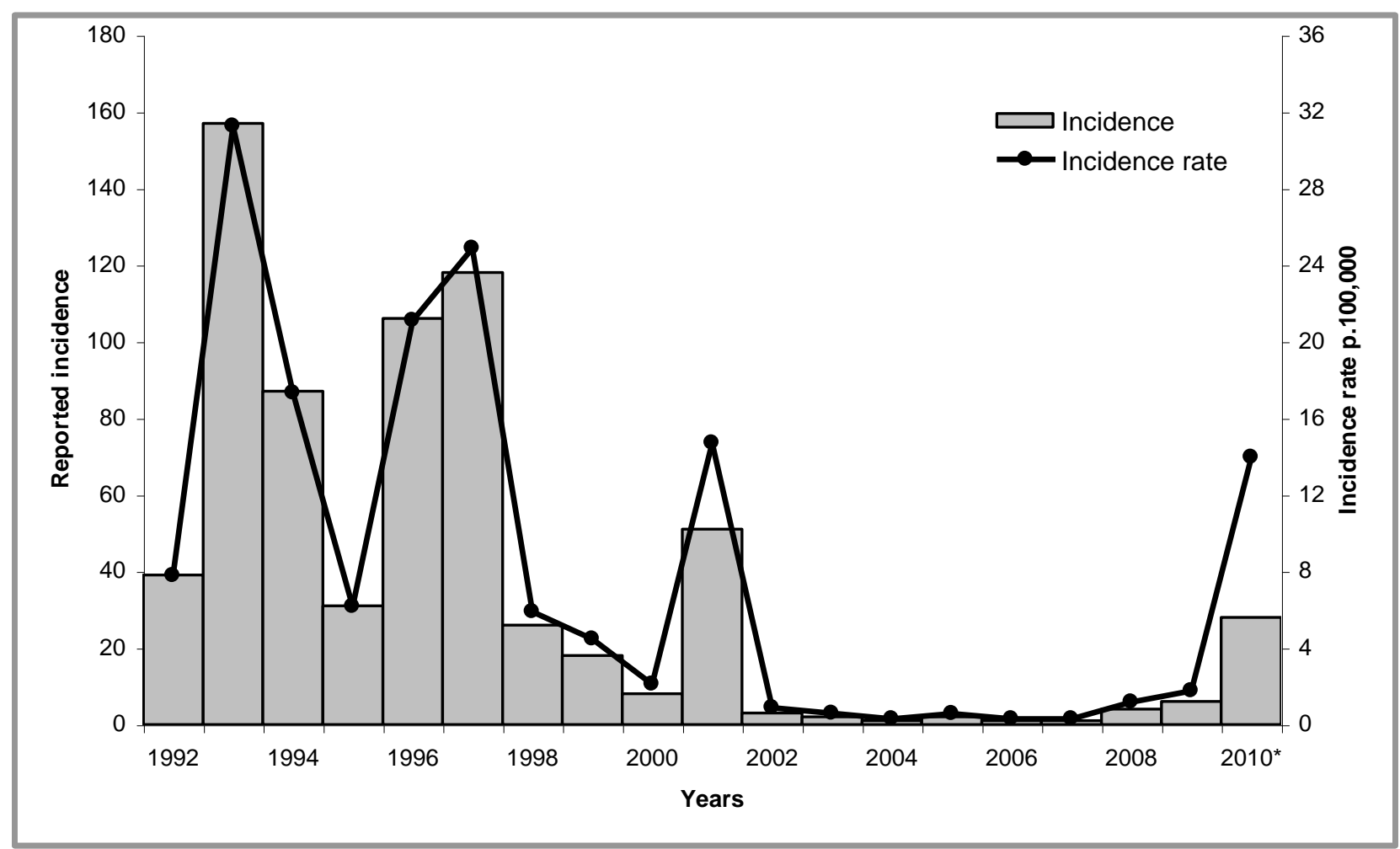

$* 1^{\text {st }}$ january to 31 july 2010

Figure 2: epidemic curve for notified cases of measles in the French armed forces between January $1^{\text {st }}$ and $31^{\text {st }}$ July 2010 in metropolitan France $(n=24)$

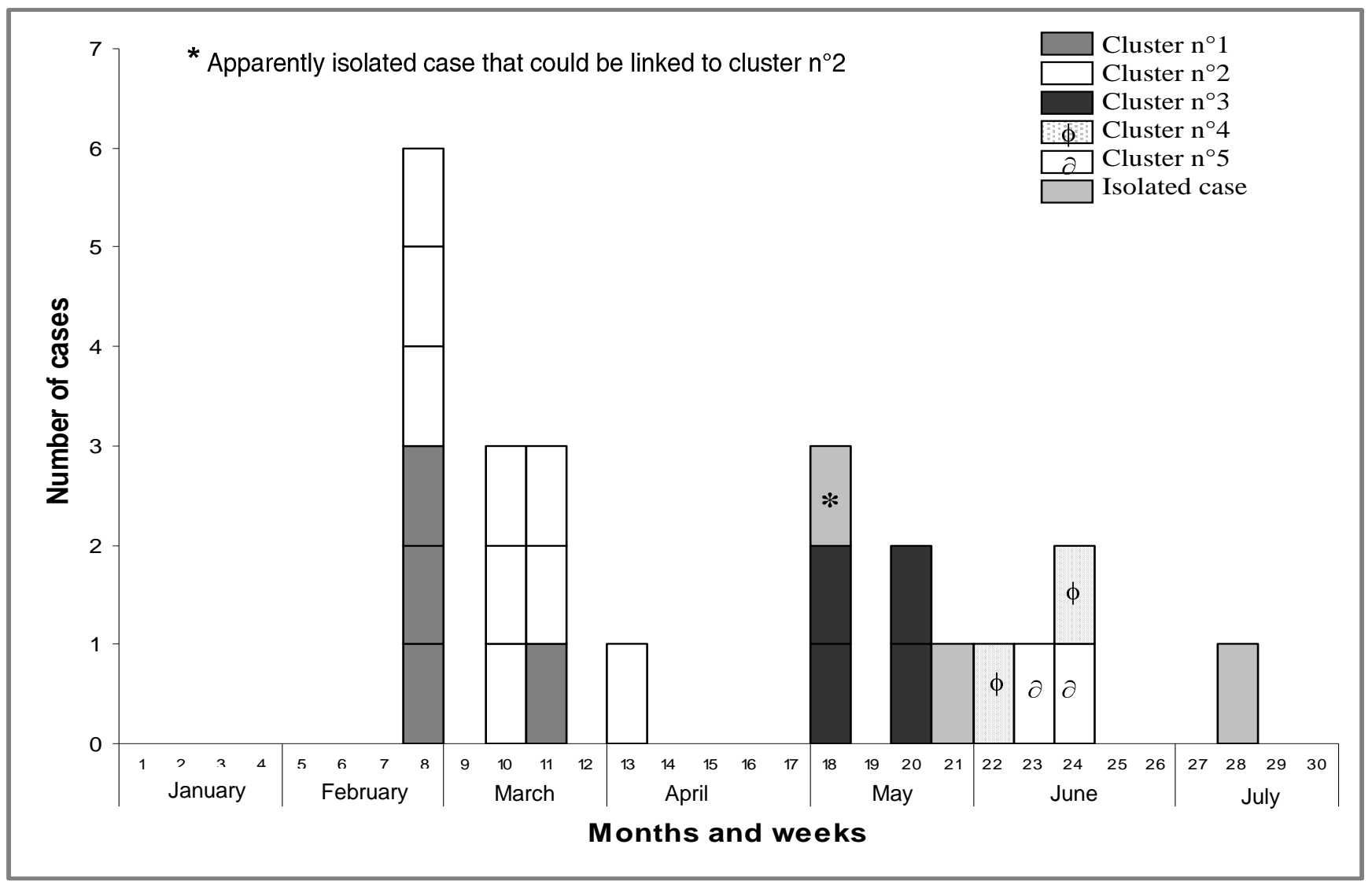

